\title{
Physiological and vegetative behavior of banana cultivars under irrigation water salinity
}

\author{
Edvaldo B. Santana Júnior ${ }^{1}$, Eugênio F. Coelho², Karoline S. Gonçalves² \& Jailson L. Cruz ${ }^{2}$ \\ ${ }^{1}$ Instituto Federal do Piauí. Paulistana, PI, Brasil. E-mail: edvaldobispo@gmail.com - ORCID: 0000-0001-6133-4096 \\ ${ }^{2}$ Embrapa Mandioca e Fruticultura. Cruz das Almas, BA, Brasil. E-mail: ecoelho@cnpmf.embrapa.br - ORCID: 0000-0001-7079-6858; karolinesg@yahoo.com.br \\ (Corresponding author) - ORCID: 0000-0002-1124-9309; jailson.cruz@cnpmf.embrapa.br - ORCID: 0000-0002-2536-6143
}

\begin{abstract}
The purpose of the study was to evaluate the effect of salinity levels of irrigation water on physiology and growth of banana cultivars during the vegetative stage. The experiment was carried out following a completely randomized design in split plots, with four levels of salinity in irrigation water $(0.5$, 2.0, 3.0 and $4.0 \mathrm{dS} \mathrm{m}^{-1}$ ) and four banana cultivars (Pacovan, Prata Anã, BRS Platina and Princesa) with three repetitions. Stomatal conductance, transpiration, relative water content, leaf water potential and proline concentration were evaluated at 150 days after transplanting (DAT), besides plant height, stem diameter and leaf area. All variables showed sensitivity to the increase of salinity level of irrigation water. The results of soil water extraction, relative water content in leaf (RWC), leaf water potential and proline content differed $(\mathrm{p} \leq 0.05)$ among the cultivars. Prata Anã and BRS Platina cultivars were the ones with lowest sensitivity, while Pacovan and BRS Princesa cultivars showed larger variation of soil water extraction and RWC with the increase in irrigation water salinity (electrical conductivity), being considered the ones of highest sensitivity to salinity in this study. Banana crop growth as a consequence of physiological effects was inhibited by the increase in water salinity, mainly in "BRS Princesa" cultivar.
\end{abstract}

Key words: Musa spp., relative transpiration, electrical conductivity, drip irrigation

\section{Comportamento fisiológico e vegetativo de cultivares de bananeira sob salinidade da água de irrigação}

RESUMO: Objetivou-se neste trabalho avaliar o efeito de níveis de salinidade da água de irrigação na fisiologia e crescimento durante a fase vegetativa em cultivares de bananeira. $O$ experimento foi conduzido utilizando delineamento inteiramente casualizado em esquema de parcelas subdivididas, com quatro níveis de salinidade da água de irrigação $\left(0,5 ; 2,0 ; 3,0\right.$ e 4,0 dS m m $\left.^{-1}\right)$ e quatro cultivares de bananeira (Prata Anã, BRS Platina, Princesa e Pacovan) com três repetições. Foram realizadas as seguintes avaliações: condutância estomática, transpiração, conteúdo relativo de água na folha, pressão de turgescência das folhas e teor de prolina, aos 150 dias após o transplantio, e altura de planta, diâmetro de caule e área foliar. Todas as variáveis avaliadas apresentaram sensibilidade ao aumento do nível de salinidade da água. Os resultados de extração de água do solo, conteúdo relativo de água, pressão de turgescência e o teor de prolina na folha diferiram ( $\mathrm{p} \leq$ 0.05) entre as cultivares. As cultivares Prata Anã e BRS Platina apresentaram menor sensibilidade, enquanto a Pacovan e BRS Princesa maior variação na extração de água do solo e no conteúdo relativo de água na folha com o aumento da salinidade da água de irrigação (condutividade elétrica) sendo consideradas as de maior sensibilidade à salinidade nesse estudo. $\mathrm{O}$ crescimento da bananeira como consequência dos efeitos na fisiologia foi inibido pelo incremento da salinidade, principalmente na cultivar BRS Princesa.

Palavras-chave: Musa spp., transpiração relativa, condutividade elétrica, gotejamento 


\section{INTRODUCTION}

Banana (Musa spp) is considered one of the most important crops commercially cultivated worldwide, with an estimated production of 113 million tons in an area of 5.6 million hectares (FAOSTAT, 2017). In Brazil, this fruit crop has significant importance, as banana is the fruit with the second largest volume of production in Brazil, only behind orange (IBGE, 2018).

The banana plant is highly sensitive to salinity, requiring irrigation water electrical conductivity values lower than $1.0 \mathrm{dS}$ $\mathrm{m}^{-1}$ for adequate development (Gondim et al., 2006). The use of irrigation water with salt contents above the limit tolerated by the crop can cause significant reduction in its growth, which may lead to severe losses in the final production.

Salinity is one of the abiotic stresses that most compromise agricultural production, especially in arid and semiarid regions, where the problems caused by salinization are even more accentuated due to the characteristics of the soil, climatic conditions and the inadequate irrigation management performed by some irrigators, which can thus favor the accumulation of salts in soil and water (Cova et al., 2016).

Salt stress can induce physiological modifications and compromise crop growth, development and production (Freire et al., 2014). In susceptible species, it is manifested by severe reductions in growth, water and photosynthetic exchange activities, disorders in membrane permeability and ionic balance (Cavalcante et al., 2010), besides damaging the stomatal conductance and/or diffusive resistance, transpiration and leaf temperature (Nascimento et al., 2011; Taiz et al., 2017). The increase in the concentration of salts in the soil solution causes the water to become increasingly less available to plants and, once the soil has reduced osmotic potential in the solution, water extraction by plants is substantially affected (Alves et al., 2011; Iqbal et al., 2014).

Studies have been conducted with saline water for banana cultivation, reporting morpho-physiological and yield alterations (Silva et al., 2009; Willadino et al., 2011; Silva Junior et al., 2012). However, most studies are focused on assessing the effects of salinity considering the banana tree in its initial stage (Silva Junior et al., 2016) and some cultivars were not adequately evaluated. Therefore, the objective of this study was to evaluate the effect of the application of irrigation water salinity on physiological and growth variables in banana cultivars.

\section{Material And Methods}

The study was carried out in the experimental field of Embrapa Mandioca e Fruticultura Tropical in the municipality of Cruz das Almas, BA, Brazil ( $12^{\circ} 40^{\prime} 19^{\prime \prime}$ S, 3906’ 23” W; $225 \mathrm{~m}$ of altitude). The climate of the region is classified as humid to sub-humid, with annual average air relative humidity and air temperature of $80 \%$ and $24^{\circ} \mathrm{C}$, respectively, and average annual rainfall of $1.170 \mathrm{~mm}$, with variation between 900 and $1.300 \mathrm{~mm}$ (Lima Filho et al., 2013) in a sandy clay loam soil, whose chemical and physico-hydraulic attributes are presented in Table 1.

The experiment was set up in a completely randomized design in a split-plot scheme. The plots were used to evaluate four irrigation water salinity $\left(0.5 ; 2.0 ; 3.0\right.$ and $\left.4.0 \mathrm{dS} \mathrm{m}^{-1}\right)$, equivalent to four soil solution salinity $(0.86 ; 2.28 ; 3.25$ and 4.58 $\mathrm{dS} \mathrm{m}^{-1}$ ), and four banana cultivars in the subplots (Prata Anã, BRS Platina, Princesa and Pacovan), with three repetitions. The salinity in the soil solution were measured by reading of the soil solution, extracted with soil solution extractors and read in a benchtop conductivity meter. The values remained constant throughout the experiment.

The field experiment consisted of 48 plastic pots with $100 \mathrm{~L}$ volume of each, height of $1.0 \mathrm{~m}$ and diameter of $0.60 \mathrm{~m}$, used as drainage lysimeters, distributed at spacing of $2.0 \times 2.5 \mathrm{~m}$. Each pot was cultivated with one banana seedling, which was already acclimated, totaling 48 plants in the area, 12 plants of each cultivar. A drainage system consisting of $8.0 \mathrm{~L}$ of crushed stone $\mathrm{n}^{\circ} 0$ and a perforated $32-\mathrm{mm}$-diameter PVC pipe connected to a 20 -mm-diameter valve was installed at the bottom of each pot.

The water used in the irrigations (Table 1) was prepared by adding sodium chloride $(\mathrm{NaCl})$ and calcium chloride $\left(\mathrm{CaCl}_{2}\right)$ in sufficient quantities to obtain electrical conductivities with ionic proportions equivalent to $3: 2$, respectively for $\mathrm{Na}^{+}$and $\mathrm{Ca}^{2+}$. The salts were added to obtain salinity of 2.0, 3.0 and 4.0 $\mathrm{dS} \mathrm{m} \mathrm{m}^{-1}$, since the salinity of $0.5 \mathrm{dS} \mathrm{m}^{-1}$ was the control treatment, with no addition of salts.

Irrigation was performed using a drip system, which had pressure-compensating emitters with flow rate of $4 \mathrm{~L} \mathrm{~h}^{-1}$. After planting the seedlings, soil moisture was monitored with two TDR probes installed in each pot, at a $0.10 \mathrm{~m}$ distance from the pseudostem and at depths of 0.20 and $0.40 \mathrm{~m}$. The water volume replaced in each irrigation was calculated from Eq. 1.

$$
\mathrm{VR}=\left(\theta_{\mathrm{fc}}-\theta_{\mathrm{a}}\right) \mathrm{V}_{\mathrm{s}} 1000
$$

where:

VR - volume ofreplacement, L;

$\theta_{\mathrm{fc}} \quad$ - moisture at field capacity, $\mathrm{m}^{3} \mathrm{~m}^{-3}$;

$\theta_{\text {a }} \quad$ - actual moisture at the moment of irrigation, $\mathrm{m}^{3} \mathrm{~m}^{-3}$; and,

$\mathrm{V}_{\mathrm{s}} \quad$ - volume of soil occupied by the plant, $\mathrm{m}^{3}$.

Table 1. Physico-hydraulic and chemical characterization of the soil and water used in the experiment

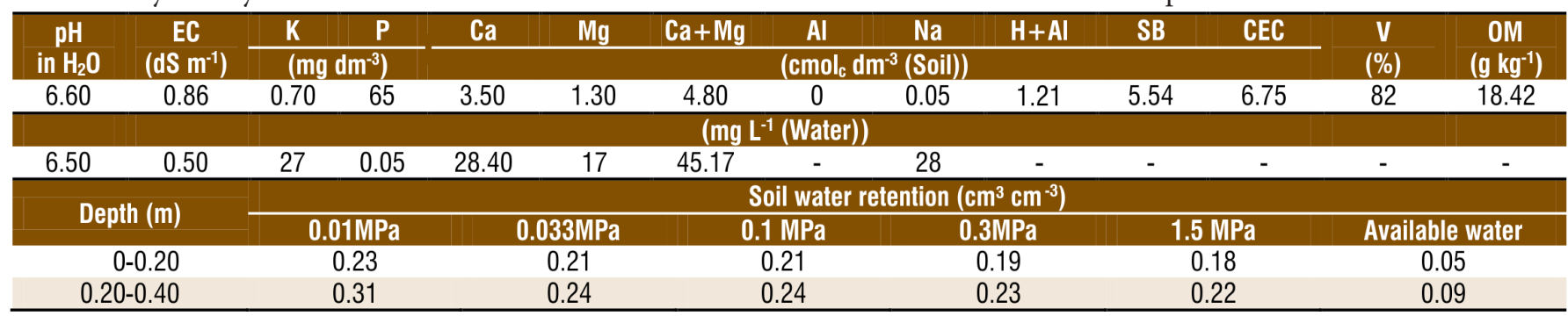

SB - Sum of bases; CEC - Cation exchanged capacity; V - Base saturation; OM - Organic matter 
In the vegetative growth stage (150 days after transplantingDAT), stomatal conductance $\left(g_{s}\right)$ measurements were performed using the Delta-T AP4 porometer, previously calibrated, at times of 9,11 and $15 \mathrm{~h}$, in all plants. The relative transpiration in the treatments under salt stress was evaluated by covering the soil surface with a plastic tarpaulin for a 6-day period, along the vegetative growth stage of the plants (150156 DAT) and, during this period, the water loss exclusively by transpiration was evaluated for $24 \mathrm{~h}$ based on the difference of moisture in the soil profile (Eqs. 2 and 3), as well as the water extraction by plants in the 150-156 DAT period, according to Eq. 4.

$$
\mathrm{TR}=\theta_{\mathrm{j}}-\theta_{\mathrm{j}+1}+\mathrm{I}+\mathrm{D}_{\mathrm{r}}
$$

where:

TR - transpired water depth, mm;

$\theta_{j} \quad$ - water depth stored in the soil volume before irrigation, $\mathrm{mm}$;

$\theta_{j+1} \quad$ - water depth stored in the soil volume after $24 \mathrm{~h}, \mathrm{~mm}$;

I - water depth infiltrated in the period $(j)-(j+1), m m$; and,

$D_{r} \quad-$ water depth drained in the period $(j)-(j+1), m m$.

The water depth stored in the soil profile at a given time was calculated by Eq. 3:

$$
\mathrm{L}=\int_{0}^{0.4} \theta \mathrm{d}_{\mathrm{z}}
$$

where:

L - water depth stored in the soil profile, m;

$\mathrm{dz}$ - soil depth, m; and,

$\theta \quad$ - volumetric soil moisture

Water extraction in the soil volume in the period $(j)-(j+1)$ was calculated by Eq. 4:

$$
\text { Ext }=\int_{0}^{0.4} \theta_{j}-\int_{0}^{0.4} \theta_{j+1}
$$

where:

Ext - water extraction in the 0-0.40 m layer, m;

$\theta$ - water depth stored at the time after irrigation, m; and,

$\theta_{j+1}$ - water depth stored in the soil before the next irrigation, $\mathrm{m}$.

The transpiration of plants under saline water application (Ts) was compared with the average of plants in the control treatment (Tns), i.e., relative to the lysimeters which received water with $\mathrm{EC}$ of $0.5 \mathrm{dS} \mathrm{m}^{-1}$, generating the relative transpiration adapted from Sinclair (1986) (Eq. 5).

$$
\mathrm{RT}=\frac{\mathrm{Ts}}{\mathrm{Tns}}
$$

where:

RT - relative transpiration;
Ts - transpiration of treatments under stress, $\mathrm{mm} \mathrm{d}^{-1}$;

Tns - transpiration of the treatment under no stress, $\mathrm{mm} \mathrm{d}^{-1}$.

Leaf relative water content (RWC) at 150 DAT was obtained according to the equation proposed by Rodríguez-Gamir et al. (2010) (Eq. 6).

$$
\mathrm{RWC}=\frac{\mathrm{FM}-\mathrm{DM}}{\mathrm{TM}-\mathrm{DM}}
$$

where:

RWC - relative water content, \%;

FM - fresh mass of leaf disc, g;

DM - dry mass of leaf disc, g; and,

TM - turgid mass of leaf disc, $g$.

Leaf turgor pressure was determined using Wiltmeter device and estimated from Eq. 7, proposed by Calbo et al. (2010). The evaluation was performed at 150 DAT using samples of leaves from the middle third of the third leaf of the banana plant, collected at 5:00 $\mathrm{h}$ in the morning.

$$
\Psi P=P_{y} \cdot f_{w}
$$

where:

$\Psi P$ - turgor pressure, $\mathrm{kPa}$;

$\mathrm{P}_{\mathrm{y}} \quad$ - pressure read on the device's manometer, $\mathrm{kPa}$; and,

$f_{w}^{y}-$ wiltmeter factor.

The free proline concentration in the leaf tissue of each cultivar at 150 DAT was determined according to the methodology of Bates et al. (1973). The amount of free proline was obtained by standard curve. The air vapor pressure deficit (VPD) was calculated from the air temperature values, used to determine the water vapor saturation pressure in the air, as proposed by Tetens (1930) (Eq. 8).

$$
\mathrm{VPD}=\mathrm{e}_{\mathrm{s}}-\mathrm{e}_{\mathrm{a}}
$$

where:

VPD - air vapor pressure deficit, $\mathrm{kPa}$;

$\mathrm{e}_{\mathrm{s}} \quad$ - air saturation vapor pressure, $\mathrm{kPa}$; and,

$\mathrm{e}_{\mathrm{a}} \quad$ - partial vapor pressure, $\mathrm{kPa}$.

Plant growth was evaluated monthly, until the flowering period, by measurements of the following variables: plant height, pseudostem diameter at $0.10 \mathrm{~m}$ from the soil, number of leaves and leaf area. Leaf area was estimated according to the methodology proposed by Moreira (1999).

The obtained data were subjected to analysis of variance and Tukey's means comparison test for cultivars at $\mathrm{p} \leq 0.05$. While regression analysis was used for electrical conductivity of irrigation water. The statistical program Sisvar was used (Ferreira, 2011).

\section{Results AND Discussion}

Stomatal conductance $\left(\mathrm{g}_{\mathrm{s}}\right)$ was influenced $(\mathrm{p} \leq 0.05)$ by the salinity of irrigation water, with no difference among 
cultivars. Stomatal conductance values were reduced as the salinity of irrigation water increased. The rate of reduction in stomatal conductance was $40.22 \mathrm{mmol} \mathrm{m}^{2} \mathrm{~s}^{-1}$ per unit of $\mathrm{dS} \mathrm{m} \mathrm{m}^{-1}$ of electrical conductivity (EC) (Figure 1).

The reduction of stomatal conductance with the increase in EC of the water applied to the soil was possibly due to the increased resistance to $\mathrm{CO}_{2}$ diffusion, caused by the high levels of irrigation water salinity in the soil solution (Silveira et al., 2010; Silva et al., 2011; Kusvuran, 2012).

The increase in the level of salts in the soil solution causes a reduction in soil water potential, which is usually higher than the root water potential. Thus, there is a reduction in the water potential gradient in the soil-root direction, with an increase in the soil water retention tension, thus compromising the absorption by roots. The reduction in stomatal conductance is a mechanism of tolerance to salinity, which reduces water losses through the ostiole and minimizes the occurrence of desiccation of the plant (Silva et al., 2014; Rodrigues et al., 2014).

The higher stomatal conductance were found in plants under application of water with EC of $0.5 \mathrm{dS} \mathrm{m}^{-1}$ in all three times during the day (Table 2). The application of water with EC equal to or above $2.0 \mathrm{dS} \mathrm{m}^{-1}$ contributes to the reduction in the total soil water potential and rises up the soil-air potential gradient. Therefore, it intensifies the impact on stomatal closure, by reducing stomatal conductance, regardless of the time, compared to the application of non-saline water of $0.5 \mathrm{dS} \mathrm{m}^{-1}$.

The increase in the salinity level in irrigation water to $2.0 \mathrm{dS} \mathrm{m}^{-1}$ resulted in a reduction in plant stomatal conductance of $36.6 \%$ (at $11: 00 \mathrm{~h}$ ), and of $49.9 \%$ in the highest saline level (EC $4.0 \mathrm{dS} \mathrm{m}^{-1}$ ), when compared to the lower salinity level $\left(\right.$ EC $0.5 \mathrm{dS} \mathrm{m}^{-1}$ ). The reduction of stomatal opening with the

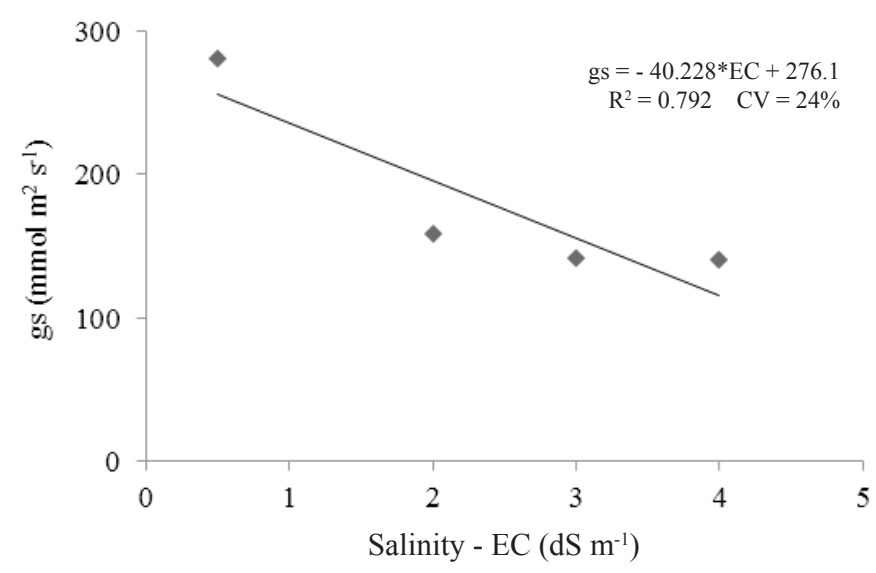

* Significant at $\mathrm{p} \leq 0.05$ by $\mathrm{F}$ test

Figure 1. Stomatal conductance (gs) in banana cultivars as a function of irrigation water salinity (EC)

Table 2. Stomatal conductance (gs) and vapor pressure deficit (VPD) in banana cultivars subjected to irrigation water salinity at three different hours of day

\begin{tabular}{|c|c|c|c|c|}
\hline \multirow{3}{*}{$\begin{array}{l}\text { Time VPD/ } \\
\text { Hour (kPa) }\end{array}$} & \multicolumn{4}{|c|}{ Stomatal conductance $\left(\mathrm{mmol}^{2} \mathrm{~s}^{-1}\right)$} \\
\hline & \multicolumn{4}{|c|}{ Salinity levels of irrigation water ( $\mathrm{dS} \mathrm{m}^{-1}$ ) } \\
\hline & 0.5 & 2.0 & 3.0 & 4.0 \\
\hline $9: 001.41$ & $204.08 \mathrm{bA}$ & $160.37 \mathrm{aB}$ & $116.53 \mathrm{aC}$ & $102.87 \mathrm{bC}$ \\
\hline $11: 00 \quad 2.18$ & $281.08 \mathrm{aA}$ & $178.01 \mathrm{aB}$ & $141.75 \mathrm{aC}$ & $140.91 \mathrm{aC}$ \\
\hline $15: 00 \quad 1.61$ & $93.54 \mathrm{cA}$ & $69.18 \mathrm{bB}$ & $72.38 \mathrm{bB}$ & $80.36 \mathrm{cB}$ \\
\hline
\end{tabular}

Means followed by the same letter, lowercase in the column and uppercase in the row do not differ statistically by Tukey test at $\mathrm{p} \leq 0.05$ increase of salinity level causes a reduction in the $\mathrm{CO}_{2}$ uptake in the photosynthetic process, which reduces considerably the net photosynthesis rate by plants, negatively affecting the growth and development of banana crop (Silva Junior et al., 2012).

With air temperature increase between 9:00h e 11:00h, there is a gradual increase in the vapor pressure deficit until it reaches a maximum value. The water potential gradient between the soil and the boundary layer of air on the leaf surface is maximum at this moment, so that the soil cannot meet the demanded flow, resulting in partial stomatal closure or reduction of stomatal conductance, which is accentuated under conditions of increased salinity (Munns \& Tester, 2008; Taiz et al., 2017).

All cultivars had linear reduction of water extraction with the increase in EC, and the largest decrease occurred in the cv. Princesa $\left(0.701 \mathrm{~mm} \mathrm{~d}^{-1} \mathrm{dS}^{-1}\right)$, followed by BRS Platina, Prata Anã and Pacovan $\left(0.393 \mathrm{~mm} \mathrm{~d}^{-1} \mathrm{dS}^{-1}\right)$, (Figure 2A). The cultivars showed different levels of sensitivity in terms of soil water extraction, consistent with the relative transpiration, which followed the same behavior.

There was difference in water extraction between the cultivars for all EC values, except for $0.5 \mathrm{dS} \mathrm{m}^{-1}$ (Table 3). The cultivar BRS Platina showed higher soil water extraction compared to Prata Anã (EC $2.0 \mathrm{dS} \mathrm{m}^{-1}$ ) and to Prata Anã (EC $3.0 \mathrm{dS} \mathrm{m}^{-1}$ ). The cultivar Princesa had lower water extraction rate under irrigation with $4.0 \mathrm{dS} \mathrm{m}^{-1}$.

The average relative transpiration (RT) of banana cultivars was not influenced by the cultivars and was reduced with the increase in the salinity level of irrigation water for all of them.
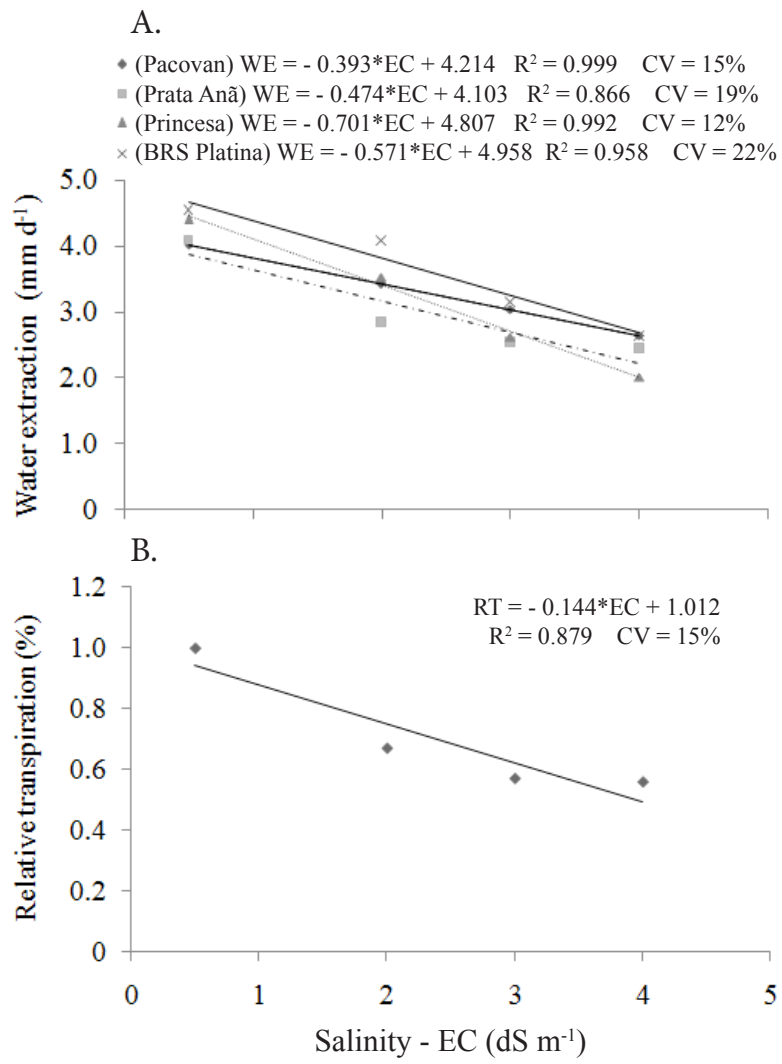

* Significant at $\mathrm{p} \leq 0.05$ by $\mathrm{F}$ test

Figure 2. Soil water extraction -WE (A) and relative transpiration - RT (B) of banana cultivars as a function of irrigation water salinity (EC) 
Table 3. Mean soil water extraction of banana cultivars irrigated with salinity levels in irrigation water

\begin{tabular}{lcccc}
\hline \multirow{3}{*}{ Cultivars } & \multicolumn{4}{c}{ Mean soil water extraction $\left(\mathbf{m m ~ d ~}^{-1}\right)$} \\
\cline { 2 - 5 } & \multicolumn{4}{c}{ Salinity levels of irrigation water $\left(\mathbf{d S ~} \mathbf{~ m}^{-1}\right)$} \\
\cline { 2 - 5 } Pacovan & $\mathbf{0 . 5}$ & $\mathbf{2 . 0}$ & 3.0 & $\mathbf{4 . 0}$ \\
Prata Anã & $4.02 \mathrm{a}$ & $3.42 \mathrm{ab}$ & $3.04 \mathrm{a}$ & $2.64 \mathrm{a}$ \\
Princesa & $4.09 \mathrm{a}$ & $2.84 \mathrm{~b}$ & $2.53 \mathrm{~b}$ & $2.45 \mathrm{a}$ \\
BRS Platina & $4.41 \mathrm{a}$ & $3.53 \mathrm{ab}$ & $2.62 \mathrm{~b}$ & $2.01 \mathrm{~b}$ \\
\hline
\end{tabular}

Means followed by the same letter in the column do not differ statistically by Tukey test at $\mathrm{p} \leq 0.05$

The rate of reduction of RT was $14.4 \%$ for unit increase of $1.0 \mathrm{dS} \mathrm{m}^{-1}$ in the electrical conductivity of irrigation water (Figure 2B).

The behavior of RT is a response of the reductions in stomatal conductance and total soil water potential as the EC increased. Stomatal conductance is responsible for the input and output flows of $\mathrm{CO}_{2}$ and water through the stomata, and the smaller the opening, the greater the stomatal resistance, resulting in a decrease of transpiration (Munns \& Tester, 2008; Taiz et al., 2017), consequently leading to losses in biometric growth and biomass by plants (Willadino et al., 2011).

The mean relative water content in the leaf (RWC) did not differ between cultivars under application of $0.5 \mathrm{dS} \mathrm{m} \mathrm{m}^{-1}$

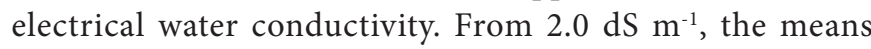
decreased with no consistency that could allow a regression model to be fitted. At EC between 2.0 and $3.0 \mathrm{dS} \mathrm{m}^{-1}$, the means of RWC that decreased the most were those of "Pacovan" and "Princesa" (Table 4).

With the application of irrigation water with EC of 4.0 $\mathrm{dS} \mathrm{m} \mathrm{m}^{-1}$, only the cultivar Prata Anã maintained the mean relative water content in the leaf above $90 \%$, which represents a reduction in RWC of only $1.37 \%$ compared to the mean obtained with the application of $0.5 \mathrm{dS} \mathrm{m}^{-1}$ water. This result indicates that the cultivar Prata Anã was able to maintain its RWC without alterations even under increased water salinity in the soil, which possibly reflects, compared to the other cultivars, the activation of mechanisms of physiological adaptation against the adversity in soil water availability (Taiz et al., 2017). The reduction of RWC in many crops is a recurrent action when there is an increase in soil salinity (Ferraz et al., 2015).

The means of turgor pressure ( $\Psi P$ ) of leaf cells differed only between the cultivars Prata Anã and BRS Princesa, which had the highest and lowest means of $\Psi$ P, respectively, confirming the relationship between RWC and the turgor pressure of leaf cells (Figure 3A). One of the justifications for the reduction in RWC, as well as in turgor pressure, especially

Table 4. Relative water content (RWC) in leaves of banana cultivars subjected to increasing salinity of irrigation water

\begin{tabular}{|ccccc}
\hline \multirow{3}{*}{ Cultivars } & \multicolumn{4}{c|}{ Relative water content (\%) } \\
\cline { 2 - 5 } & \multicolumn{4}{c}{ Salinity levels of irrigation water (dS $\mathbf{m}^{-1}$ ) } \\
\cline { 2 - 5 } & $\mathbf{0 . 5}$ & $\mathbf{2 . 0}$ & $\mathbf{3 . 0}$ & $\mathbf{4 . 0}$ \\
Pacovan & $91.38 \mathrm{a}$ & $90.99 \mathrm{a}$ & $85.92 \mathrm{~b}$ & $82.87 \mathrm{~b}$ \\
Prata Anã & $92.19 \mathrm{a}$ & $90.54 \mathrm{a}$ & $93.23 \mathrm{a}$ & $90.82 \mathrm{a}$ \\
\hline Princesa & $92.11 \mathrm{a}$ & $83.55 \mathrm{~b}$ & $85.45 \mathrm{~b}$ & $85.98 \mathrm{~b}$ \\
\hline BRS Platina & $89.18 \mathrm{a}$ & $88.55 \mathrm{a}$ & $89.00 \mathrm{a}$ & $82.94 \mathrm{~b}$ \\
\hline
\end{tabular}

Means followed by the same lowercase letter in the column do not differ statistically by Tukey test at $\mathrm{p} \leq 0.05$

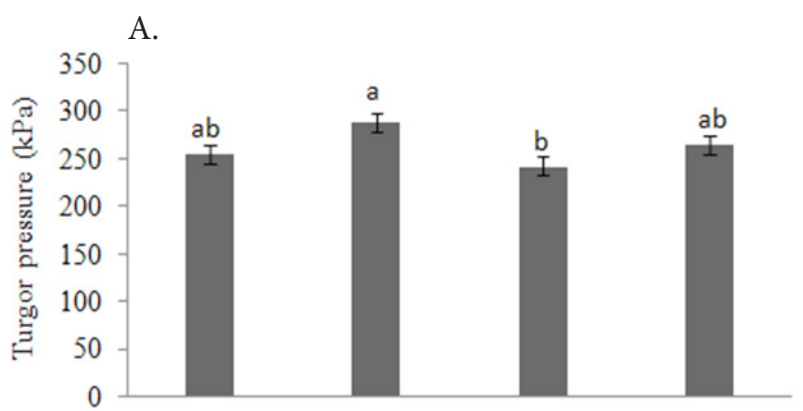

B.

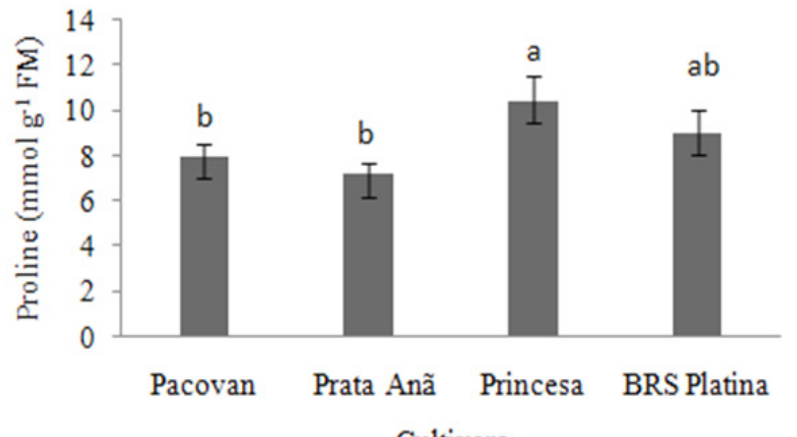

Cultivars

Columns represent the mean and bars represent \pm the standard error of the mean; Bars with different letters are significant at $\mathrm{p} \leq 0.05$ by Tukey test; FM - Fresh matter

Figure 3. Turgor pressure in leaf cells (A) and proline concentration in leaves (B) of banana cultivars subjected to irrigation water salinity

in the cultivar BRS Princesa, may be the accumulation of high contents of $\mathrm{Na}^{+}$and $\mathrm{Cl}^{-}$in the leaves (Silva Junior et al., 2016; Taiz et al., 2017).

The cultivars influenced the leaf proline concentration, and the highest mean was observed in the cv. Princesa, differing statistically from the cultivars Pacovan and Prata Anã. The mean leaf proline concentration of the cultivar BRS Platina had an intermediate value, not differing statistically from those observed in the other cultivars (Figure 3B).

The highest proline concentration in the cultivar Princesa associated with higher rate of reduction in water extraction and lower mean of the turgor potential are approached as metabolic disorders induced by the accumulation of salts in the leaves, especially $\mathrm{Na}^{+}$and $\mathrm{Cl}^{-}$(Oliveira et al., 2013), suggesting that this cultivar is more sensitive to salt stress.

Plant height was inhibited with the increase of salinity (EC) for all cultivars. The ranges of reduction in plant height as the irrigation water electrical conductivity increased were higher for the $\mathrm{cv}$. Princesa and lower for the cv. BRS Platina (Figure $4 \mathrm{~A}$ ), a situation that confirm that the $\mathrm{cv}$. "Princesa" is the most sensitive to salts compared to the others, thus reinforcing that banana genotypes may respond differently when subjected to salt stress (Silva Junior et al., 2012).

Reductions in the growth of plants subjected to salinity are directly associated with the reduction in their water absorption due to the decrease in the osmotic potential of the soil solution, caused by the accumulation of soluble salts from irrigation waters, and to the decrease in the absorption of essential nutrients (Munns \& Tester, 2008), caused by ionic imbalance (Iqbal et al., 2014).

The average pseudostem diameter and number of leaves 
A.

- (Pacovan) $\mathrm{PH}=-0.141 * \mathrm{EC}+2.599 \quad \mathrm{R}^{2}=0.819 \quad \mathrm{CV}=15 \%$

- (Prata Anã) $\mathrm{PH}=-0.092 * \mathrm{EC}+1.776 \quad \mathrm{R}^{2}=0.834 \quad \mathrm{CV}=13 \%$

$\Delta$ (Princesa) $\mathrm{PH}=-0.143 * \mathrm{EC}+2.446 \mathrm{R}^{2}=0.792 \quad \mathrm{CV}=22 \%$

$\times$ (BRS Platina) $\mathrm{PH}=-0.067 * \mathrm{EC}+1.795 \mathrm{R}^{2}=0.953 \quad \mathrm{CV}=12 \%$

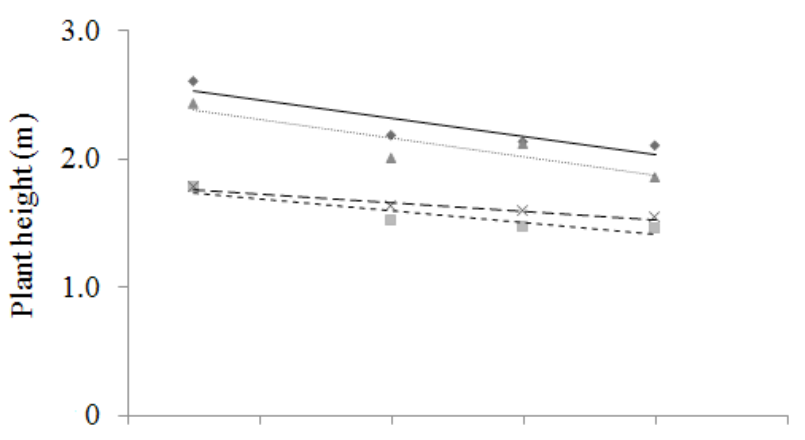

B.

- (300 DAT) $\mathrm{LA}=-0.213 * * \mathrm{EC}+3.197 \quad \mathrm{R}^{2}=0.932 \quad \mathrm{CV}=17 \%$ =(350 DAT) $\mathrm{LA}=-0.403 * * \mathrm{EC}+4.220 \quad \mathrm{R}^{2}=0.950 \quad \mathrm{CV}=15 \%$

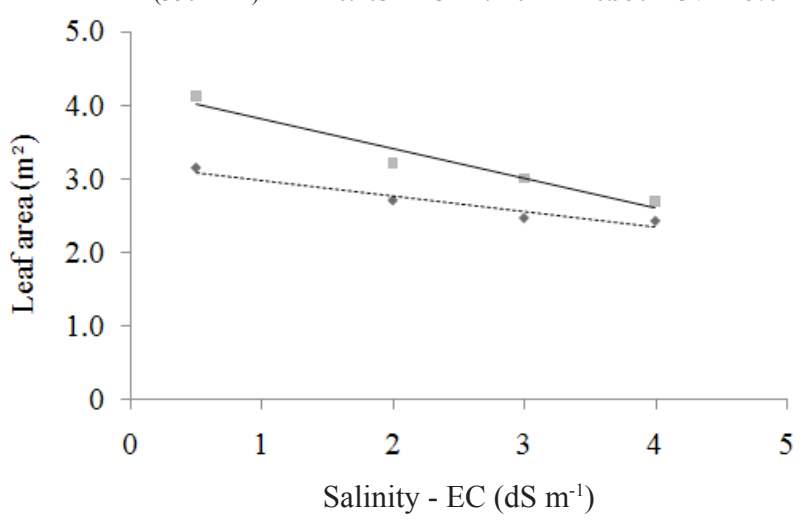

*, ** - Significant at $\mathrm{p} \leq 0.05$ and $\mathrm{p} \leq 0.01$, respectively, by $\mathrm{F}$ test

Figure 4. Plant height - $\mathrm{PH}$ at 350 days after transplanting (DAT) in banana cultivars (A) and leaf area - LA for all cultivars at 300 and 350 DAT (B), as a function of electrical irrigation water salinity - EC

were not affected by the salinity levels. The leaf area of banana cultivars was affected by the salinity levels (Figure 4B). The rate of reduction in leaf area per salinity level in the evaluated period (350 DAT) corresponded to $0.403 \mathrm{~m}$ per unit of $\mathrm{dS} \mathrm{m} \mathrm{m}^{-1}$.

Reduction of leaf area in banana genotypes as a function of the increment in soil salinity levels has been widely reported (Silva et al., 2009; Silva Junior et al., 2012; Willadino et al., 2011), which can possibly be considered as a mechanism of adaptation of the plant to water deficit in soil.

\section{Conclusions}

1. The increase in irrigation water salinity inhibited stomatal conductance and transpiration of banana cultivars.

2. Due to the higher capacity for soil water extraction, higher relative water content and higher turgor pressure in the leaves, the cultivars BRS Platina and Prata Anã were the ones with highest tolerance, while Pacovan and Princesa were the most sensitive to the increase in irrigation water salinity.

3. The increase in irrigation water salinity inhibited the growth in plant height in the following order: Princesa $>$ Pacovan $>$ PrataAnã > BRS Platina and leaf area in all banana cultivars.

\section{Literature Cited}

Alves, F. A. L.; Silva, S. L. F.; Silveira, J. A. G.; Pereira, V. L. A. Efeito do $\mathrm{Ca}^{2+}$ externo no conteúdo de $\mathrm{Na}^{+}$e $\mathrm{K}^{+}$em cajueiros expostos a salinidade. Revista Brasileira de Ciências Agrárias, v.6, p.602608, 2011. https://doi.org/10.5039/agraria.v6i4a1257

Bates, L. S.; Waldren, R. P.; Teare, I. D. Rapid determination of free proline for water-stress studies.Plant and Soil, v.39, p.205-207, 1973. https://doi.org/10.1007/BF00018060

Calbo, A. G. A.; Ferreira, M. D.; Pessoa, J. D. C. Leaf lamina compression method for estimating turgor pressure. HortScience, v.45, p.418-423, 2010. https://doi.org/10.21273/ HORTSCI.45.3.418

Cavalcante, L. F.; Cordeiro, J. C.; Nascimento, J. A. M. Cavalcante, I. H. L.; Dias, T. J. Fontes e níveis da salinidade da água na formação de mudas de mamoeiro cv. Sunrise solo. Revista Brasileira de Ciências Agrárias, v.31, p.1281-1290, 2010. https:// doi.org/10.5433/1679-0359.2010v31n4Sup1p1281

Cova, A. M. W.; Azevedo Neto, A. D. de; Ribas, R. F.; Gheyi, H. R.; Menezes, R. V. Effect of salt stress on growth and contents of organic and inorganic compounds in noni (Morinda citrifolia L.). African Journal of Biotechnology, v.15, p.2401-2410, 2016. https://doi.org/10.5897/AJB2016.15591

FAOSTAT. Área colhida, rendimento e produção nos principais países produtores de bananeira - 2017. Available at: <http:// faostat.fao.org >. Accessed on: Jun 18, 2019.

Freire, J. L. O.; Dias, T. J.; Cavalcante, L. F.; Fernandes, P. D.; Lima Neto, A. J. de. Rendimento quântico e trocas gasosas em maracujazeiro amarelo sob salinidade hídrica, biofertilização e cobertura morta. Revista Ciência Agronômica, v.45, p.82-91, 2014. https://doi.org/10.1590/S1806-66902014000100011

Ferraz, R. L. de S.; Magalhães, I. D.; Beltrão, N. E. de M.; Melo, A. S. de; Brito Neto, J. F. de B.; Rocha, M. do S. Photosynthetic pigments, cell extrusion and relative leaf water content of the castor bean under silicon and salinity. Revista Brasileira de Engenharia Agrícola e Ambiental, v.19, p.841-848, 2015. https:// doi.org/10.1590/1807-1929/agriambi.v19n9p841-848

Ferreira, D. F. Sisvar: A computer statistical analysis system. Ciência e Agrotecnologia, v.35, p.1039-1042, 2011. https://doi. org/10.1590/S1413-70542011000600001

Gondim, A. R. de O.; Medeiros, J. F. de; Carmo, G. A. do; Pereira, F. H. F.; Gheyi, H. R.; Tavares, J. C. Produtividade de banana submetida a diferentes níveis de salinidade da água de irrigação: segundo ciclo. Revista Brasileira de Engenharia Agrícola e Ambiental, v.10, p.38-42, 2006. https://doi.org/10.1590/S141543662006000100006

IBGE - Instituto Brasileiro de Geografia e Estatística. Produção agrícola. 2018. Available at: https://sidra.ibge.gov.br/home/lspa/ brasil.Accessed on: Jun 18, 2019.

Iqbal, N.; Umar, S.; Khan, N. A.; Khan, M. I. R. A new perspective of phytohormones in salinity tolerance: Regulation of proline metabolism. Environmental and Experimental Botany, v.100, p.34-42, 2014. https://doi.org/10.1016/j.envexpbot.2013.12.006

Kusvuran, S. Effects of drought and salt stresses on growth, stomatal conductance, leaf water and osmotic potentials of melon genotypes (Cucumis melo L.). African Journal Agricultural Research, v.7, p.775-781, 2012. https://doi.org/10.5897/ AJAR11.1783 
Lima Filho, A. F.; Coelho Filho, M. A. C.; Heinemann, A. B. Determinação de épocas de semeadura do feijão caupi no Recôncavo Baiano através do modelo CROPGRO. Revista Brasileira de Engenharia Agrícola e Ambiental, v.17, p.1294-1300, 2013. https://doi.org/10.1590/S1415-43662013001200007

Moreira, R. S. Banana: Teoria e prática de cultivo. 2.ed. Campinas: Fundação Cargill, 1999. CD-Rom.

Munns, R.; Tester, M. Mechanisms of salinity tolerance. Annual Review of Plant Biology, v.59, p.651-681, 2008. https://doi. org/10.1146/annurev.arplant.59.032607.092911

Nascimento, J. A. M.; Cavalcante, L. F.; Santos, P. D.; Silva, S. A.; Silva, M. V.; Oliveira, A. P. Efeito da utilização de biofertilizante bovino na produção de mudas de pimentão irrigadas com água salina. Revista Brasileira Ciências Agrárias, v.6, p.258-264, 2011. https:// doi.org/10.5039/agraria.v6i2a1069

Oliveira, V. P. de; Marques, E. C.; Lacerda, C. F. de; Prisco, J. T.; Gomes Filho, E. Physiological and biochemical characteristics of Sorghum bicolor and Sorghum sudanense subjected to salt stress in two stages of development. African Journal of Agricultural Research, v.8, p.660-670, 2013.

Rodrigues, C. R. F.; Silva, E. N.; Moura, R. da M.; Anjos, D. C. dos; Hernandez, F. F. F.; Viégas, R. A. Physiological adjustment to salt stress in R. communis seedlings is associated with a probable mechanism of osmotic adjustment and a reduction in water lost by transpiration. Industrial Crops and Products, v.54, p.233-239, 2014. https://doi.org/10.1016/j.indcrop.2013.12.041

Rodríguez-Gamir, J.; Primo-Millo, E.; Forner, J. B.; Forner-Giner, M. A. Citrus rootstock responses to water stress. Scientia Horticulturae, v.126, p.95-102, 2010. https://doi.org/10.1016/j. scienta.2010.06.015

Silva, E. N.; Ribeiro, R. V.; Silva, S. L. F.; Viégas, R. A.; Silveira, J. A. G. Salt stress induced damages on the photosynthesis of physic nut young plants. Scientia Agrícola, v.68, p.62-68, 2011. https:// doi.org/10.1590/S0103-90162011000100010
Silva, L. A.; Brito, M. E. B.; Sá, F. V. S.; Moreira, R. C. L.; Soares Filho, W. S.; Fernandes, P. D. Mecanismos fisiológicos em híbridos de citros sob estresse salino em cultivo hidropônico. Revista Brasileira de Engenharia Agrícola e Ambiental, v.18, p.1-7, 2014. https://doi.org/10.1590/1807-1929/agriambi.v18nsupps1-s7

Silva, R. L. O.; Martins, L. S. S.; Gomes, E. W. F.; Ferraz, G. M. G.; Silva, S. O.; Willadino, L. Avaliação de diplóides de bananeira (Musa spp.) quanto à tolerância a salinidade. Revista Brasileira de Fruticultura, v.31, p.1084-1091, 2009. https://doi.org/10.1590/ S0100-29452009000400023

Silva Junior, G. S.; Willadino, L. G.; Camara, T. R.; Silva, L. E. Comportamento estomático em genótipos diplóides de bananeira submetidos ao estresse salino. Revista Cientec, v.4, p.33-43, 2012.

Silva Junior, G. S.; Willadino, L. G; Silva, L. E.; Camara, T. R.; Efeito da salinidade sobre o desequilíbrio nutricional em genótipos diplóides de bananeiras. Revista Cientec, v.8, p.20-29, 2016.

Silveira, J. A. G.; Silva, S. L. F.; Silva, E. N.; Viégas, R. A. Mecanismos biomoleculares envolvidos com a resistência ao estresse salino em plantas. In: Gheyi, H. R.; Dias, N. daS.; Lacerda, C. F. de. Manejo da salinidade na agricultura: Estudos básicos e aplicados. 1.ed. Fortaleza: INCTSal. 2010. Cap.11, p.161-18.

Sinclair, T. R. Water and nitrogen limitations in soybean grain production I. Model development. Field Crops Research, v.15, p.125-141, 1986. https://doi.org/10.1016/0378-4290(86)90082-1

Taiz, L.; Zeiger, E.; Moller, I. M.; Murphy, A. Fisiologia e desenvolvimento vegetal. 6.ed. Porto Alegre: Artmed, 2017. 888p.

Tetens, V. O. Über einige meteorologische begriffe. Zeitschrift Geophysic, v.6, p.297-309, 1930.

Willadino, L.; Gomes, E. W. F.; Silva, E. F. de F. e; Martins, L. S. S.; Camara, T. R. Efeito do estresse salino em genótipos tetraplóides de bananeira. Revista Brasileira de Engenharia Agrícola e Ambiental, v.15, p.53-59, 2011. https://doi.org/10.1590/S141543662011000100008 